\title{
PENGARUH MODEL PEMBELAJARAN THINK PAIR SHARE MENGGUNAKAN MEDIA MIND MAPPING TERHADAP AKTIVITAS DAN HASIL BELAJAR KOGNITIF SISWA
}

\author{
Rukiah Lubis ${ }^{1}$, Meti Herlina ${ }^{2}$, Jeni Rukmana ${ }^{3}$ \\ Universitas Muhammadiyah Bengkulu ${ }^{1,2,3}$ \\ Rukiah2507@gmail.com ${ }^{1}$
}

\begin{abstract}
ABSTRAK
Penelitian ini bertujuan untuk mengetahui pengaruh model pembelajaran think pair share menggunakan media mind mapping terhadap aktivitas dan hasil belajar kognitif siswa kelas X IPA SMAN 06 Kota Bengkulu. Jenis penelitian ini yaitu quasi eksperimen dengan desain Non-Randomized Design. Sampel diambil 2 kelas dari 4 kelas dengan cara melihat nilai rata-rata siswa yang hampir sama yaitu kelas X IPA A sebagai kelas eksperimen dan X IPA B sebagai kelas kontrol. Instrument yang digunakan berupa lembar observasi aktivitas siswa dan soal test kognitif. Berdasarkan penskoran hasil lembar observasi aktivitas siswa kelas eksperimen lebih tinggi dibandingkan dengan kelas kontrol yaitu 58.56 dan rata-rata hasil posttest yaitu 85.69 sedangakan lembar observasi aktivitas siswa kelas kontrol yaitu 53.97 dan rata-rata hasil posttest yaitu 63.03. Hasil uji-t variabel aktivitas siswa diperoleh nilai Sig sebesar $0.000<0.05$ hasil uji-t hasil belajar kognitif siswa diperoleh nilai $p$-value sebesar $0.000<0.05$, yang berarti ada perbedaan skor aktivitas dan hasil kognitif siswa sebelum dan sesudah pemberian intervensi model pembelajaran think pair share menggunakan media mind mapping. Simpulan, model pembelajaran Think Pair Share dengan media Mind Mapping memberikan pengaruh secara signifikan terhadap aktivitas dan hasil belajar kognitif siswa.
\end{abstract}

Kata Kunci : aktivitas, hasil belajar, mind mapping, think pair share

\section{ABSTRACT}

This study aims to determine the effect of think pair share learning models using mind mapping media on the activities and cognitive learning outcomes of class $X$ science students of SMAN 06 Bengkulu City. This type of research is a quasi-experimental design with Non-Randomized Design. Samples were taken from 2 classes of 4 classes by looking at the mean scores of students who are almost the same, namely class $X$ Natural Sciences A as the experimental class and Natural Sciences B as a control class. The instrument used was in the form of student activity observation sheets and cognitive test questions. Based on scoring the results of the observation sheet of the experimental class student activity was higher than the control class that was 58.56 and the average posttest result was 85.69 while the observation sheet of the activity class of the control class was 53.97 and the average posttest result was 63.03. Student activity variable t-test results obtained Sig value of 0,000<0.05 t-test results 
of student cognitive learning results obtained p-value of 0,000 $<0.05$, which means there are differences in activity scores and cognitive outcomes of students before and after the intervention of the learning model think pair share using media mind mapping. In conclusion, Think Pair Share learning model with Mind Mapping media has an influence on students' cognitive learning activities and outcomes.

Keywords: activities, learning outcomes, mind mapping, think pair share

\section{PENDAHULUAN}

Pendidikan sangat penting bagi kehidupan seseorang. Pendidikan bermaksud untuk mengembangkan kecerdasan, keterampilan, serta potensi peserta didik yang pada akhirnya bertanggung jawab pada diri sendiri dan orang lain. Pendidikan merupakan usaha sadar dan terencana yang dilakukan oleh pendidik melalui bimbingan, pengajaran, dan latihan untuk mewujudkan suasana belajar dan proses pembelajaran agar peserta didik aktif yang mengarah pada tercapainya pribadi yang dewasa (pasal 1 ayat 1 UU No.20 Tahun 2003).

Menurut Pusparini (2015) banyak permasalahan pada pendidikan di Indonesia sekarang ini. Semakin maju dan beragam kehidupan manusia maka semakin beragam pula permasalahan pendidikan, mulai dari kurikulum yang terus berubah, para pendidik yang kurang profesional, dan kualitas hasil pendidikan yang dianggap belum memadai. Kualitas pendidikan yang banyak disoroti yaitu kualitas dalam proses kegiatan pembelajaran di kelas. Kegiatan pembelajaran di kelas merupakan inti dari penyelenggaraan pendidikan yang meliputi pengelolaan kelas, penggunaan media dan sumber belajar, penggunaan metode pembelajaran, serta strategi pembelajaran. Hal ini berarti bahwa berhasil atau tidaknya pencapaian pendidikan banyak bergantung kepada bagaimana proses belajar mengajar dirancang dan dijalankan secara profesional.

Upaya yang dapat dilakukan berkaitan dengan peningkatan kualitas proses kegiatan pembelajaran di kelas adalah dengan membangun pembelajaran secara mandiri dan guru hanya sebagai fasilitator. Perubahan paradigma dalam proses pembelajaran yang tadinya berpusat pada guru (Teacher Centered) menjadi pembelajaran yang berpusat pada peserta didik (Student Centered) diharapkan dapat mendorong peserta didik untuk terlibat secara aktif dalam membangun pengetahuan, sikap, dan keterampilan. Pembelajaran yang interaktif terjadi multi arah, yaitu peran guru tetap penting ketika proses pembelajaran berlangsung. Tugas guru untuk mentransfer pengetahuan dan nilai-nilai atau sikap yang baik tetap dibutuhkan oleh peserta didik (Prasetyawati, 2016).

Peserta didik memiliki perbedaan karena faktor-faktor yang mempengaruhi proses belajar siswa dan hasil yang diinternalisasi meliputi: sikap terhadap belajar, minat dan motivasi belajar, konsentrasi belajar, sedangkan faktor eksternal meliputi 
hal-hal seperti : guru sebagai pelatih belajar, infrastruktur dan fasilitas belajar, kebijakan penilaian, lingkungan sosial siswa di sekolah dan di rumah serta kurikulum sekolah. Pelajari sesuatu yang menarik perhatian, akan lebih mudah diterima daripada dalam mempelajari hal-hal yang tidak menarik perhatian, belajar ini juga tidak bisa dianggap remeh atau tidak penting (Maesaroh, 2013)

Kegiatan observasi awal pada mata pelajaran biologi kelas X IPA disekolah dengan cara wawancara dengan Ibu Dra. Silviani Gusmali selaku guru mata pelajaran biologi peneliti mendapatkan data jika guru menggunakan model pembelajaran seperti Ceramah, Diskusi, dan Discovery Learning model pembelajaran digunakan bergantian sesuai dengan materi pembelajaran. Pada saat observasi dikelas, peneliti mendapatkan data yang menunjukan bahwa siswa yang aktif bertanya masih sedikit hanya sebanyak $\pm 5 \%$ dari jumlah siswa didalam kelas. Sebanyak $\pm 10 \%$ siswa yang aktif mejawab pertanyaan yang diajukan oleh guru, $\pm 2 \%$ yang berani mengemukakan pendapat, $\pm 2 \%$ aktif menganggapi atau menyanggah pendapat teman dan guru pada saat pembelajaran.

Hasil ini disebabkan oleh karena siswa masih merasa takut mengemukakan pendapat karena merasa jawaban yang tidak tepat, padahal guru tidak pernah menyalahkan jika siswa mengemukakan pendapat yang tidak tepat sehingga siswa menjadi kurang aktif. Hal ini mengakibatkan hasil belajar siswa belum optimal dapat dilihat dari hasil ujian tengah semester (UTS) pada kelas X IPA A semester ganjil tahun ajaran 2018/2019 didapati hanya 28.6\% yang nilainya diatas KKM sedangkan sebanyak 71.4\% nilainya dibawah KKM, begitu juga dengan kelas X IPA B semester ganjil tahun ajaran 2018/2019 didapati hanya 18.2\% yang nilainya diatas KKM sedangkan sebanyak $81.8 \%$ nilainya dibawah KKM. Banyaknya nilai siswa yang belum mencukupi KKM dikarenakan siswa tidak mampu menguasai dan mengingat materi serta dipengaruhi juga oleh ketertarikan siswa dalam mengikuti pembelajaran.

Menurut Samitra et.al (2018) model pembelajaran Guided Note Taking berpengaruh terhadap hasil belajar biologi siswa. Sedangkan menurut Rozi et.al (2018) aktivitas belajar biologi siswa lebih meningkat setelah diberikan perlakuan dengan menggunakan model Cooperative Script. Nesi \& Akobiarek (2018) menyatakan terdapat pengaruh yang sangat signifikan antara metode pembelajaran dan minat atau pengaruh metode terhadap hasil belajar IPA. Kemudian, science comic berpengaruh terhadap hasil belajar siswa (Kurniawati et.al, 2018). Model pembelajaran discovery learning dapat meningkatkan hasil belajar dan aktivitas belajar siswa (Sundari, 2018). Terjadi peningkatan hasil belajar biologi dengan menerapkan metode mind mapping (Elita, 2018). Terdapat pengaruh penggunaan media video pembelajaran terhadap hasil belajar biologi siswa kelas (Yendrita \& Syafitri, 2019) 
Oleh karena itu peneliti mencoba menggunakan model pembelajaran Think pair share (TPS) sebagai upaya agar tercipta suasana pembelajaran yang mampu mempengaruhi aktifitas dan hasil belajar kognitif siswa serta menggunakan media Mind Mapping agar proses pembelajaran lebih menarik dan materi yang diajarkan lebih lama untuk diingat.

Model Think Pair Share dapat membuat peserta didik aktif belajar bersama dengan teman lainnya untuk berdiskusi dan menyampaikan hasil diskusi di depan pasangan kelompok lainnya (Marlina et al, 2017). Guru juga memberikan kesempatan siswa untuk menjawab dengan asumsi pemikirannya sendiri, kemudian berpasangan untuk mendiskusikan hasil jawabannya kepada teman sekelas untuk dapat didiskusikan dan dicari pemecahannya bersama-sama sehingga terbentuk suatu konsep yang saling mempengaruhi diantara siswa dengan siswa lainnya (Bakri, 2014)

Untuk meningkatkan pemahaman siswa tentang materi biologi yang telah dipelajari dan dapat memahami isinya dengan mudah serta menyimpan pemahaman lebih lama maka digunakan media Mind Mapping, sehingga pemahaman yang sudah terbentuk melalui pembelajaran model Think pair share dapat terus tersimpan dengan pengingatan yang lama.

Mind Mapping adalah cara termudah untuk menempatkan informasi ke dalam otak dan mengambil informasi ke luar dari otak. Mind Mapping adalah cara yang kreatif, efektif, dan secara harfiah akan memetakan pikiran-pikiran kita, selain itu Mind Mapping juga sederhana (Burzan, 2010). Mind Mapping (peta pikiran) adalah pembelajaran dengan cara menuliskan tema utama sebagai titik sentral/tengah dan memikirkan cabang-cabang atau tema-tema turunan yang keluar dari titik tengah tersebut dan mencari hubungan antar tema turunan (Suryanto, 2009).

\section{METODE PENELITIAN}

Metode yang digunakan pada penelitian ini merupakan penelitian kuantitatif dengan pendekatan quasi eksperimen. Desain penelitian ini menggunakan rancangan non-randomized control design populasi terdapat 4 kelas IPA di kelas X SMAN 06 Kota Bengkulu yaitu X IPA A, X IPA B, X IPA C, dan X IPA D kemudian akan dipilih berdasarkan nilai rata-rata untuk menentukan kelas eksperimen dan kelas kontol. Rancangan penelitian ini adalah sebagai berikut :

$\begin{array}{cccc}\text { Kelas } & \text { Pretest } & \text { Perlakuan } & \text { Postest } \\ \text { A } & \text { Y I } & \text { X 1 } & \text { Y2 } \\ \text { B } & \text { Y I } & \text { X } 0 & \text { Y2 }\end{array}$

Skema 1. Bentuk Design Penelitian 
Keterangan :

A : Kelas eksperimen

B : Kelas kontrol

XI : Perlakuan berupa pembelajaran TPS dengan menggunakan Mind Mapping

X0 : Kelas kontrol

Y1 : Pretest (tes awal sebelum perlakuan)

Y2 : Posttest (tes akhir setelah perlakuan)

Instrumen yang digunakan untuk mengumpulkan data dalam penelitian ini adalah tes kognitif dan lembar observasi aktivitas belajar siswa dalam menyusun dan melaksanakan tes kognitif dan lembar observasi aktivitas belajar siswa dilakukan. Analisis terhadap data penelitian dilakukan bertujuan untuk menguji kebenaran hipotesis yang diajukan dalam penelitian. Analisis data yang digunakan yaitu dengan uji t dependen, proses pengolahan datanya dengan menggunakan program komputer Static For Social Science (SPSS) for window. Sebelum melakukan uji terlebih dahulukan dilakukan uji prasyarat yaitu, uji normalitas, dan uji homogenitas.

\section{HASIL PENELITIAN}

\section{Data Aktivitas Belajar Siswa}

Aktivitas belajar siswa diperoleh dari lembar observasi yang diisi oleh 2 guru biologi dan 1 mahasiswa biologi yang melakukan penelitian mengenai aktivitas belajar siswa di SMA lain sebagai observer pada saat pembelajaran berlangsung. Data hasil observasi aktivitas dapat dilihat pada table 1 berikut ini.

Table 1. Data Hasil Pengamatan Aktivitas Siswa

\begin{tabular}{ccccc}
\hline \multirow{2}{*}{ Pertemuan Ke- } & \multicolumn{2}{c}{ Kelas eksperimen } & \multicolumn{2}{c}{ Kelas kontrol } \\
\cline { 2 - 5 } & Jumlah skor & Rata-rata & Jumlah skor & Rata-rata \\
\hline I & 695 & 19.31 & 583 & 17.67 \\
\hline II & 709 & 19.69 & 599 & 18.15 \\
\hline III & 704 & 19.56 & 599 & 18.15 \\
\hline Total & 2108 & 58.56 & 1781 & 53.97 \\
\hline
\end{tabular}

Berdasarkan tabel 1 jumlah skor dan rata-rata dari pertemuan 1 hingga pertemuan 3 diketahui bahwa jumlah skor kelas eksperimen sebesar 2108 dan skor rata-rata sebesar 58.56 sedangkan jumlah skor kelas kontrol sebesar 1781 dan skor rata-rata sebesar 53.97 jika dipersentasekan skor aktivitas siswa kelas eksperimen yaitu sebesar 92.9\% sedangkan aktivitas pada kelas kontrol sebesar 85.6\%. Data hasil pengamatan aktivitas siswa diatas dapat dibuat grafik sebagai berikut : 


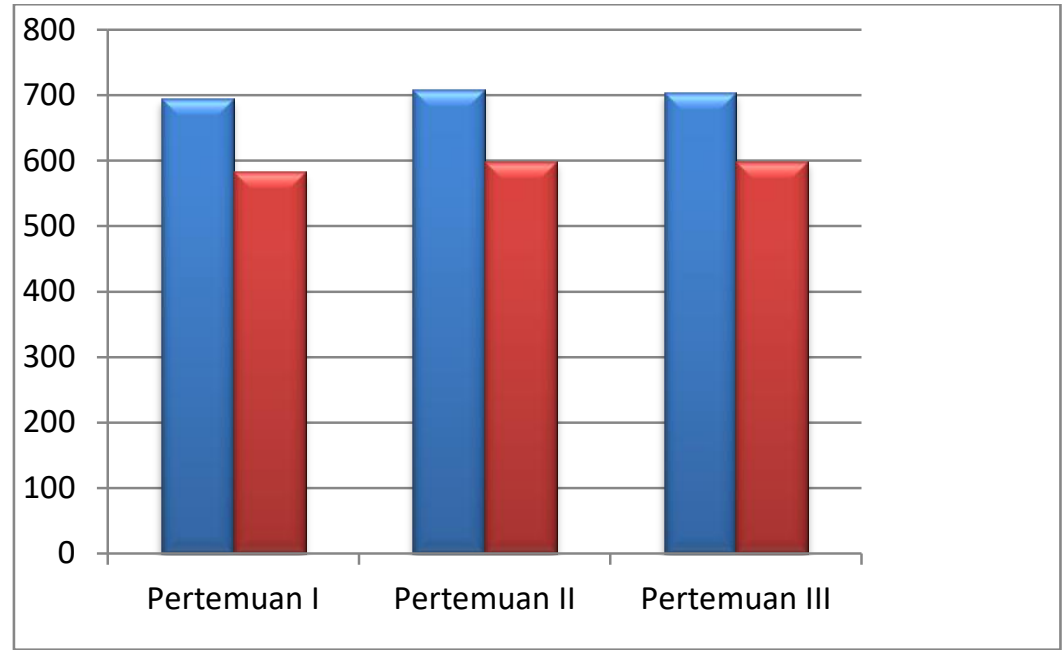

Kelas Kontrol

Kelas Eksperimen

Gambar 1. Grafik Perbandingan

Pada grafik diatas diketahui bahwa skor aktivitas siswa dari pertemuan pertama hingga pertemuan ketiga bersifat statis. Skor aktivitas siswa kelas eksperimen mengalami kenaikan pada pertemuan kedua dan mengalami penurunan pada pertemuan ketiga. Sedangkan skor aktivitas siswa kelas kontrol mengalami kenaikan pada pertemuan kedua dan bersifat tetap pada pertemuan ketiga

\section{Pengujian Prasyarat Analisis Aktifitas Belajar Siswa}

Untuk mengetahui pengaruh model pembelajaran Think Pair Share menggunakan media Mind Mapping terhadap aktivitas belajar siswa dapat dilakukan dengan uji t. Sebelum melakukan uji t akan dilakukan uji prasyarat terlebih dahulu yaitu uji normalitas dan uji homogenitas.

\section{Uji Normalitas}

Tabel 2. Hasil Uji Normalitas Data Aktivitas Belajar Siswa

\begin{tabular}{llr}
\hline & & Aktivitas Belajar Siswa \\
\hline $\mathrm{N}$ & & 36 \\
\hline Normal Parameters & & 58.39 \\
& Mean & 2.246 \\
\cline { 2 - 3 } & Std. Deviation & .155 \\
\hline Most Extreme Differences & Absolute & .123 \\
\cline { 2 - 3 } & Positive & -.155 \\
\cline { 2 - 3 } & Negative & .932 \\
\hline Kolmogorov-Smirnov Z & & .351 \\
\hline Asymp. Sig. (2-tailed) & & \\
\hline
\end{tabular}


Berdasarkan tabel 2 dapat dilihat bahwa signifikan uji normalitas sebesar 0.351 yang artinya lebih besar dari $0.05(0.351>0.05)$ sehingga dapat disimpulkan bahwa skor aktivitas belajar siswa berdistribusi normal.

\section{Uji Homogenitas}

Tabel 3. Hasil Uji Homogenitas Data Aktivitas Belajar Siswa

\begin{tabular}{cccc}
\hline \multicolumn{5}{c}{ Test of Homogeneity of Variances } \\
\hline \multicolumn{5}{c}{ Aktivitas Siswa } \\
\hline Levene Statistic & Df1 & Df2 & Sig. \\
\hline 792 & 2 & 105 & .456 \\
\hline
\end{tabular}

Berdasarkan tabel 3 dapat dilihat bahwa signifikan uji homogenitas sebesar 0.456 yang artinya lebih besar dari $0.05(0.456>0.05)$ sehingga dapat disimpulkan bahwa data aktivitas belajar siswa mempunyai varians yang homogen.

\section{Uji T}

Hasil perhitungan uji independent t-test dengan menggunakan aplikasi IBM SPSS 20.0 berikut :

Tabel 4. Hasil Uji Independent T-Test Aktivitas Belajar Siswa

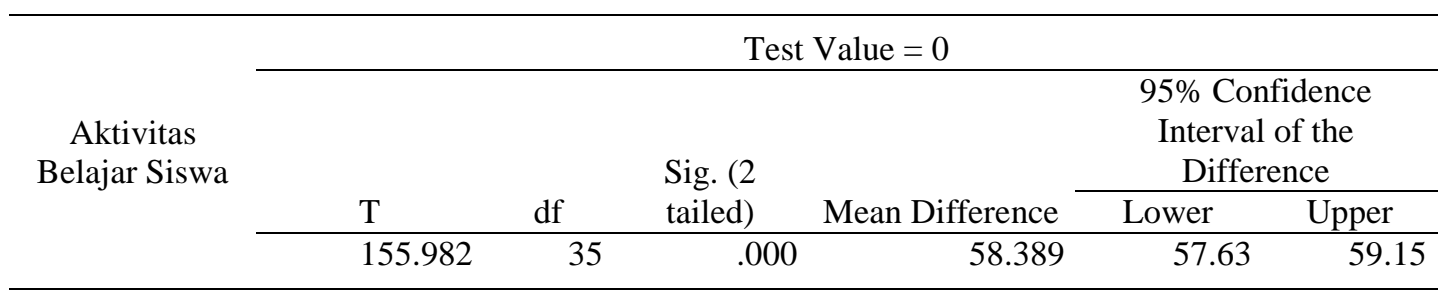

Hasil uji t diperoleh nilai $p$-value sebesar 0.000 lebih kecil dari 0.05 (0.000 < .005) maka $\mathrm{H}_{0}$ ditolak dan $\mathrm{H}_{1}$ diterima hal ini berarti bahwa terdapat pengaruh model pembelajaran Think Pair Share menggunakan media Mind Mapping terhadap aktivitas belajar siswa.

\section{Analisis Data Hasil Belajar Kognitif Siswa Analisis Data Pre-Test}

Pretest diberikan untuk mengetahui pengetahuan awal siswa mengenai materi pembelajaran yang akan diberikan sesuai model pembelajaran pada setiap kelas. Data hasil Pretest dapat dilihat pada tabel berikut : 
Tabel 5. Data Hasil Pretest Siswa

\begin{tabular}{lcccc}
\hline \multicolumn{1}{c}{ Kelas } & Jumlah Siswa & Skor Terendah & Skor Tertinggi & Rata-rata \\
\hline Pretest Kelas Eksperimen & 36 & 10 & 60 & 29.86 \\
\hline Pretest Kontrol & 33 & 10 & 60 & 28.79 \\
\hline
\end{tabular}

Berdasarkan tabel 5 dapat dilihat bahwa nilai rata-rata kelas eksperimen yaitu sebesar 29.86 sedangkan nilai rata-rata kelas kontrol yaitu sebesar 28.79 yang mengindikasikan bahwa kedua kelas tersebut tidak memiliki perbedaan yang signifikan. Selanjutnya dilakukan uji prasyarat yaitu uji normalitas dan uji homogenitas sebelum melakukan uji hipotesis.

\section{Uji Normalitas}

Uji normalitas untuk kelas eksperimen dan kelas kontrol dapat dilihat pada tabel 6 berikut ini.

Tabel 6. Hasil Uji Normalitas Data Skor Pretest

\begin{tabular}{|c|c|c|c|}
\hline \multicolumn{4}{|c|}{ Kolmogorov-Smirnov Test } \\
\hline & & Pretest Eksperimen & Pretest Kontrol \\
\hline $\mathrm{N}$ & & 36 & 33 \\
\hline \multirow{2}{*}{ Normal Parameters ${ }^{\mathrm{a}, \mathrm{b}}$} & Mean & 29.8611 & 28.7879 \\
\hline & Std. Deviation & 11.24316 & 10.82750 \\
\hline \multirow[t]{3}{*}{ Most Extreme Differences } & Absolute & .167 & .152 \\
\hline & Positive & .167 & .152 \\
\hline & Negative & -.107 & -.087 \\
\hline Kolmogorov-Smirnov Z & & 1.004 & .875 \\
\hline Asymp. Sig. (2-tailed) & & .266 & .427 \\
\hline
\end{tabular}

Berdasarkan tabel 6 di atas dapat dilihat bahwa signifikan uji normalitas Pretest kelas eksperimen sebesar 0.266 yang artinya lebih besar dari 0.05 sedangkan uji normalitas kelas kontrol sebesar 0.427 yang artinya lebih besar dari 0.05 sehingga dapat disimpulkan bahwa skor Pretest siswa berdistribusi normal.

\section{Uji Homogenitas}

Tabel 7. Hasil Uji Homogenitas Data Pretest

\begin{tabular}{cccc}
\hline \multicolumn{4}{c}{ Test of Homogeneity of Variances } \\
\hline \multicolumn{4}{c}{ Hasil Pretest } \\
\hline Levene Statistic & df1 & df2 & Sig. \\
\hline .087 & 1 & 66 & .769 \\
\hline
\end{tabular}

Berdasarkan tabel 7 di atas dapat dilihat bahwa signifikan uji homogenitas sebesar 0.769 yang artinya lebih besar dari 0.05 sehingga dapat disimpulkan bahwa data pretest siswa mempunyai varians yang homogen. 


\section{Uji T}

Hasil perhitungan uji independent t-test dengan menggunakan IBM SPSS 20.0 berikut

Tabel 8. Hasil Uji Independent T-Test Pretest:

\begin{tabular}{|c|c|c|c|c|c|c|c|c|c|c|}
\hline \multicolumn{11}{|c|}{ Independent Samples Test } \\
\hline & & \multirow[t]{2}{*}{$\mathrm{F}$} & \multirow[t]{2}{*}{ Sig. } & \multirow[t]{2}{*}{$\mathrm{t}$} & \multirow[t]{2}{*}{$\mathrm{df}$} & \multirow[t]{2}{*}{$\begin{array}{l}\text { Sig. (2- } \\
\text { tailed) }\end{array}$} & \multirow[t]{2}{*}{$\begin{array}{c}\text { Mean } \\
\text { Difference }\end{array}$} & \multirow[t]{2}{*}{$\begin{array}{l}\text { Std. Error } \\
\text { Difference }\end{array}$} & \multicolumn{2}{|c|}{$\begin{array}{c}95 \% \\
\text { Confidence } \\
\text { Interval of } \\
\text { Difference }\end{array}$} \\
\hline & & & & & & & & & Lower & Upper \\
\hline \multirow{2}{*}{$\begin{array}{c}\text { Hasil } \\
\text { Pretest }\end{array}$} & $\begin{array}{c}\text { Equal } \\
\text { variances } \\
\text { assumed }\end{array}$ & .134 & .715 & .403 & 67 & .688 & 1.073 & 2.662 & -4.241 & 6.387 \\
\hline & $\begin{array}{c}\text { Equal } \\
\text { variances } \\
\text { not } \\
\text { assumed }\end{array}$ & & & .404 & 66.828 & .688 & 1.073 & 2.658 & -4.232 & 6.378 \\
\hline
\end{tabular}

Hasil uji t diperoleh nilai $p$-value sebesar 0.668 lebih besar dari 0.05 berarti bahwa tidak terdapat pengaruh yang signifikan antara kelas eksperimen dan kelas kontrol sebelum diberi perlakuan. Karena uji t yang di dapat tidak terdapat pengaruh maka pada analisis nilai selanjutnya digunakan nilai posttest.

\section{Analisis Data Posttest}

Posttest diberikan untuk mengetahui pemahaman siswa mengenai materi pembelajaran yang telah diberikan sesuai model pembelajaran pada tiap kelas. Data hasil posttest dilihat pada tabel berikut :

Tabel 9 Data Hasil Posttest Siswa

\begin{tabular}{c|c|c|c|c}
\hline Kelas & $\begin{array}{c}\text { Jumlah } \\
\text { Siswa }\end{array}$ & Skor Terendah & Skor Tertinggi & Rata-rata \\
\hline Posttest Eksperimen & 36 & 70 & 100 & 85.69 \\
\hline Posttest Kontrol & 33 & 50 & 80 & 63.03 \\
\hline
\end{tabular}

Berdasarkan tabel 9 dapat dilihat bahwa hasil posttest kelas eksperimen memiliki skor terendah yaitu 70, skor tertinggi yaitu 100, dan skor rata-rata sebesar 85.69 dari 36 siswa. Sedangkan hasil posttest kelas kontrol memiliki skor terendah 50, skor tertinggi 80, dan skor rata-rata sebesar 63.03 dari 33 siswa. Selanjutnya dilakukan uji prasyarat yaitu uji normalitas dan uji homogenitas sebelum melakukan uji t. 


\section{Uji Normalitas}

Uji normalitas untuk kelas eksperimen dan kelas kontrol dapat dilihat pada tabel 10 berikut ini.

Tabel 10 Hasil Uji Normalitas Data Postest

\begin{tabular}{lrrr}
\hline & \multicolumn{2}{c}{ Kolmogorov-Smirnov Test } \\
\hline & & Posttest_Eksperimen & Posttest_Kontrol \\
\hline $\mathrm{N}$ & & 36 & 33 \\
\hline Normal Parameters & & 63.03 & 28.7879 \\
\cline { 2 - 5 } & 85.69 & 9.265 & 10.82750 \\
\hline Most Extreme & 7.383 & .204 & .152 \\
\cline { 2 - 5 } Differences & .141 & .204 & .152 \\
\cline { 2 - 5 } & .141 & -.138 & -.087 \\
\hline Kolmogorov-Smirnov Z & -.137 & .845 & 1.172 \\
\hline Asymp. Sig. (2-tailed) & & .473 & .128 \\
\hline
\end{tabular}

Berdasarkan tabel 10 dapat dilihat bahwa signifikan uji normalitas Posttest kelas eksperimen sebesar 0.473 yang artinya lebih besar dari 0.05 sedangkan uji normalitas kelas kontrol sebesar 0.128 yang artinya lebih besar dari 0.05 sehingga dapat disimpulkan bahwa skor Posttest siswa berdistribusi normal.

\section{Uji Homogenitas}

Tabel 11 Hasil Uji Homogenitas Data Postest

\begin{tabular}{cccc}
\hline \multicolumn{4}{c}{ Test of Homogeneity of Variances } \\
\hline \multicolumn{4}{c}{ Hasil Pretest } \\
\hline Levene Statistic & df1 & df2 & Sig. \\
\hline 3.675 & 1 & 67 & .060 \\
\hline
\end{tabular}

Berdasarkan tabel 11 dapat dilihat bahwa signifikan uji homogenitas sebesar 0.060 yang artinya lebih besar dari 0.05 sehingga dapat disimpulkan bahwa data posttest siswa mempunyai varians yang homogen.

\section{Uji T}

Tabel 12 Hasil Uji Independent T-Test Posttest

\begin{tabular}{|c|c|c|c|c|c|c|c|c|c|c|}
\hline \multicolumn{11}{|c|}{ Independent Samples Test } \\
\hline & & \multirow[t]{2}{*}{$\mathrm{F}$} & \multirow[t]{2}{*}{ Sig. } & \multirow[t]{2}{*}{$\mathrm{T}$} & \multirow[t]{2}{*}{$\mathrm{df}$} & \multirow[t]{2}{*}{$\begin{array}{l}\text { Sig. (2- } \\
\text { tailed) }\end{array}$} & \multirow{2}{*}{$\begin{array}{c}\text { Mean } \\
\text { Difference }\end{array}$} & \multirow{2}{*}{$\begin{array}{l}\text { Std. Error } \\
\text { Diff }\end{array}$} & \multicolumn{2}{|c|}{$\begin{array}{c}95 \% \text { Confidence } \\
\text { Interval of } \\
\text { Difference } \\
\end{array}$} \\
\hline & & & & & & & & & Lower & Upper \\
\hline $\begin{array}{c}\text { Hasil } \\
\text { Posttest }\end{array}$ & $\begin{array}{c}\text { Equal } \\
\text { variances } \\
\text { assumed }\end{array}$ & 3.675 & .060 & $\begin{array}{c}11.28 \\
3\end{array}$ & 67 & .000 & 22.664 & 2.009 & 18.655 & 26.674 \\
\hline
\end{tabular}




\begin{tabular}{|c|c|c|c|c|c|c|c|c|c|c|}
\hline \multicolumn{11}{|c|}{ Independent Samples Test } \\
\hline & & \multirow[t]{2}{*}{$\mathrm{F}$} & \multirow[t]{2}{*}{ Sig. } & \multirow[t]{2}{*}{$\mathrm{T}$} & \multirow[t]{2}{*}{$\mathrm{df}$} & \multirow{2}{*}{$\begin{array}{l}\text { Sig. (2- } \\
\text { tailed) }\end{array}$} & \multirow{2}{*}{$\begin{array}{c}\text { Mean } \\
\text { Difference }\end{array}$} & \multirow{2}{*}{$\begin{array}{l}\text { Std. Error } \\
\text { Diff }\end{array}$} & \multicolumn{2}{|c|}{$\begin{array}{l}\text { 95\% Confidence } \\
\text { Interval of } \\
\text { Difference } \\
\end{array}$} \\
\hline & & & & & & & & & Lower & Upper \\
\hline $\begin{array}{c}\text { Hasil } \\
\text { Posttest }\end{array}$ & $\begin{array}{c}\text { Equal } \\
\text { variances } \\
\text { assumed }\end{array}$ & 3.675 & .060 & $\begin{array}{c}11.28 \\
3\end{array}$ & 67 & .000 & 22.664 & 2.009 & 18.655 & 26.674 \\
\hline & $\begin{array}{c}\text { Equal } \\
\text { variances not } \\
\text { assumed }\end{array}$ & & & $\begin{array}{c}11.17 \\
2\end{array}$ & $\begin{array}{c}61.15 \\
0\end{array}$ & .000 & 22.664 & 2.029 & 18.608 & 26.720 \\
\hline
\end{tabular}

Hasil uji t seperti pada tabel 12 berikut ini diperoleh nilai $p$-value atau sebesar 0.000 lebih besar dari $0.05(0.000<0.05)$, ini berarti terdapat pengaruh model TPS menggunakan media Mind Mapping terhadap hasil belajar biologi pada materi dunia tumbuhan (Plantae) di kelas X IPA SMAN 06 Kota Bengkulu.

\section{PEMBAHASAN}

\section{Pengaruh Model Pembelajaran Think Pair Share Menggunakan Media Mind} Mapping Terhadap Aktivitas Siswa

Berdasarkan hasil perhitungan uji-t tabel 4 diperoleh nilai $\rho$ value sebesar 0.000 lebih kecil dari $0.05(0.000<0.05)$ berarti terdapat pengaruh model pembelajaran TPS menggunakan media Mind Mapping terhadap aktivitas belajar siswa kelas X IPA di SMAN 06 Kota Bengkulu. Hal ini berpengaruh dikarenakan proses pembelajaran di kelas melalui model pembelajaran TPS menggunakan media Mind Mapping akan memberikan banyak waktu kepada siswa untuk melakukan kegiatan pembelajaran dan akan memicu siswa untuk memecahkan masalah yang ada dalam LKPD secara individu setelah selesai mereka akan berdiskusi dengan teman sebangku dan menyampaikan argumentnya masing-masing mengenai jawaban.

Sejalan dengan pendapat Surraya, et al (2014) bahwa Teknik pembelajaran Think Pair Share memberi siswa kesempatan untuk bekerja sendiri serta bekerja sama dengan orang lain. Heriadi (2015) menyatakan bahwa pembelajaran menggunakan model TPS membuat siswa mempunyai banyak waktu untuk melakukan aktivitasaktivitas dalam kegiatan pembelajaran. Muslima, et al (2015) menjelaskan bahwa model pembelajaran kooperatif tipe TPS (Think Pair Share) memberikan kesempatan kepada siswa untuk berfikir secara mandiri pada tahap think dan memperoleh informasi dan tambahan pemahaman pada tahap pair dan sharing dengan adanya diskusi.

Hasil perhitungan data aktivitas siswa dari tabel 4 mulai dari pertemuan pertama hingga pertemuan ketiga diketahui bahwa jumlah skor aktivitas siswa kelas eksperimen yaitu 2108 dan memperoleh rata-rata sebesar 58.56 jika dipersentasekan 
sebesar 92.9\% maka dapat disimpulkan bahwa aktivitas belajar siswa sangat aktif karena siswa melakukan aktivitas yang terdapat dalam indikator dengan baik dapat dilihat pada pedoman penilaian tabel 3.6. Hal ini disebabkan siswa tidak canggung dalam bertanya kepada guru dan siswa dapat bertukar pikiran dalam menyelesaikan masalah dibimbing dengan guru. Didukung oleh pendapat Aunurrahman (2010) menyatakan bahwa keaktifan siswa dalam kelompok dapat diwujudkan dalam saling bertukar pikiran melalui komunikasi dengan pasangannya maupun kelompok lainnya. Lie (2008) menambahkan bahwa aktivitas siswa akan meningkat dengan adanya kerjasama antar anggota kelompok melalui diskusi. Begitu juga dengan pendapat Muslima (2015) yang menyatakan bahwa peran guru dalam proses pembelajaran ini yaitu membuat pembelajaran menjadi menarik dan menjadi fasilitator serta mengajak siswa dalam proses pembelajaran.

Pada lembar observasi yang dinilai oleh observer terdapat tujuh indikator aktivitas siswa pada lampiran 11. Setiap siswa sudah melakukan kegiatan tersebut dengan baik seperti siswa mengerjakan soal LKPD yang diberikan guru dan aktif bertanya kepada guru jika ada hal yang belum jelas namun membuat mereka tidak berdiskusi kembali didukung oleh pendapat Khodijah, et al (2016) bahwa siswa sudah berinisiatif untuk bertanya kepada guru jika mengalami kesulitan dalam proses pembelajaran. Solikhin (2015) juga berpendapat bahwa pada Siklus II peningkatan keberanian siswa bertanya kepada guru apabila menemui hal-hal yang menurut mereka belum paham atau dirasakan sulit.

Pada indikator 7 siswa mempresentasikan hasil diskusi mereka tetapi karena banyaknya kelompok maka kelompok presentasi dibatasi tidak semua kelompok dapat mempresentasikan hasil kerja mereka ke depan kelas. Di dukung oleh pendapat Saputra, et al (2015) bahwa rendahnya aktivitas siswa pada indikator persentasi disebabkan guru membatasi jumlah siswa yang persentasi, yaitu 1 pasangan dari beberapa kelompok.

Berdasarkan data grafik 1 bahwa skor aktivitas siswa kelas eksperimen mengalami kenaikan pesat pada pertemuan kedua dan mengalami penurunan pada pertemuan ketiga. Hal ini terjadi karena siswa lebih banyak menghabiskan waktu untuk mengerjakan LKPD sehingga waktu untuk presentasi hasil diskusi mereka menjadi berkurang sependapat dengan Saenab, et al (2017) Siswa mempergunakan waktu yang lebih banyak untuk mengerjakan LKS dan mencari jawaban, sehingga waktu untuk melakukan sharing di depan kelas menjadi berkurang dan tidak maksimal. Adapun Rosba (2015) menyatakan bahwa Aktivitas A.6 (mengerjakan LKS) siswa mengerjakan LKS dengan bimbingan guru dari pertemuan pertama sebanyak $74 \%$ ke pertemuan kedua mengalami peningkatan sebanyak $83 \%$ dengan selisih $9 \%$. 
Selain itu penelitian ini terkendala oleh waktu pembelajaran yang terpotong proses perkenalan pada pertemuan pertama dan perpisahan pada pertemuan ketiga. Dengan demikian dapat disimpulkan bahwa data aktivitas siswa bersifat statis yang mengalami kenaikan dan penurunan. Hal ini disebabkan model pembelajaran TPS menggunakan media Mind Mapping menyita banyak waktu dan membutuhkan koordinasi yang tepat pada setiap aktivitas yang dilakukan selama proses pembelajaran berlangsung. Sejalan dengan pendapat Amalia, et al (2014) bahwa guru akan mengalami kesulitan dalam membimbing siswa yang membutuhkan perhatian lebih dan jika jumlah siswa banyak maka siswa akan memerlukan banyak waktu untuk mempresentasikan hasil diskusi karena jumlah kelompok atau pasangan yang cukup besar. Dina (2018) menjelaskan, adapun kekurangan dari model pembelajaran TPS di antaranya : Banyak kelompok yang akan melaporkan tugasnya pada guru, Guru harus memonitor banyak kelompok, Butuh banyak waktu, Jika ada perselisihan tidak ada penengah.

Mind Mapping juga mempengaruhi aktivitas siswa dalam proses pembelajaran menggunakan model TPS. Hal ini disebabkan karena Mind Mapping akan memberikan kemudahan kepada siswa pada aktivitas Visual, Oral, Listening, Writing, dan Drawing untuk menuangkan ide mereka dalam bentuk kreasi karena jawaban tidak hanya dalam penjelasan tapi juga bisa berupa kata kunci. Sependapat dengan Silberman (2007) Mind Mapping adalah cara kreatif bagi peseta didik secara individual untuk menghasilkan ide-ide mencatat pelajaran, atau merencanakan penelitian baru. Selain itu siswa akan lebih leluasa dalam memahami materi karena mereka sudah tahu konsepnya bukan hanya sekedar menghafal bahasa buku. Wulandari (2014) menjelaskan Mind Mapping adalah cara mencatat yang kreatif, efektif, dan memetakan apa yang ada pada pikiran kita. Hastutin, et al (2012) menambahkan jika Mind Map merupakan penunjang dalam kegiatan pembelajaran biologi yang dapat mendukung kegiatan siswa untuk berfikir dan bekerjasama yang baik dalam menyelesaikan persoalan-persoalan selama proses pembelajaran biologi berlangsung.

Selain itu Mind Mapping akan mempengaruhi pada aktivitas Mental dan Emotional, siswa akan leluasa mempresentasikan hasil kerja mereka karena telah memahami konsep yang mereka buat sendiri dibandingkan dengan menjelaskan menggunakan bahasa buku. Wardhani, et al (2014) menjelaskan jika Mind Map membuat siswa dapat belajar semakin efektif dan efesien dengan berfikir reduktif yaitu dengan cara merangkum informasi yang banyak kedalam konsep-konsep utama yang saling berhubungan kedalam sebuah diagram atau gambar jauh lebih kuat disbanding dengan mengingat sebuah susunan kalimat. Hal ini sejalan dengan pendapat Heriadi (2015) yang menyatakan jika Mind Mapping membuat anggota 
kelompok dapat bekerjasama dengan baik serta mampu mengembangkan konsepkonsep yang telah didapat menjadi lebih bermakna dalam pembelajaran kooperatif.

\section{Pengaruh Model Pembelajaran Think Pair Share Menggunakan Media Mind Mapping Terhadap Hasil Belajar Kognitif Siswa}

Hasil perhitungan uji-t diperoleh $\rho$ value sebesar 0.000 lebih kecil dari 0.05 $(0.000<0.05)$ maka $\mathrm{H}_{0}$ ditolak dan $\mathrm{H}_{1}$ diterima berarti terdapat pengaruh model pembelajaran TPS menggunakan media Mind Mapping terdapat pengaruh model pembelajaran TPS menggunakan media Mind Mapping terhadap hasil belajar kognitif siswa kelas X IPA di SMAN 06 Kota Bengkulu. Hal ini terjadi karena model pembelajaran TPS akan melibatkan siswa secara maksimal dalam proses pembelajaran.

Hasil penelitian ini didukung oleh pendapat Lestari, et al (2016) yang menjelasakan jika model cooperative learning tipe think pair share merupakan model pembelajaran yang melibatkan peserta didik secara maksimal dalam kegiatan pebelajaran mulai dari merencanakan topik-topik yang akan dipelajari, bagaimana mendiskusian topik suatu materi, hingga melakukas presentasi kelompok dan evaluasi. Selain itu model TPS memberi kesempatan yang lebih banyak kepada siswa untuk berfikir sehingga meningkatkan daya ingat siswa terhadap informasi, dan saling memghargai pendapat satu sama lain sehingga dapat mempengaruhi pola berfikir siswa. Penelitian ini sejalan dengan pendapat Nuyami, et al (2014) bahwa Dengan model pembelajaran TPS siswa juga belajar menghargai pendapat orang lain, meningkatkan kemampuan siswa dalam mengingat suatu informasi, dapat belajar dari siswa lain serta saling menyampaikan idenya untuk didiskusikan.

Hasil posttest siswa pada tabel 4. diketahui bahwa skor rata-rata yang diperoleh siswa sudah bagus yaitu 85.69 karena seluruh siswa mencapai bahkan melebihi KKM. Hal ini berarti siswa telah menguasai dan lebih memahami materi pembelajaran yang diterapkan model pembelajaran TPS menggunakan Mind Mapping. Sependapat dengan Alfiyana, et al (2016) bahwa Hasil belajar siswa dengan menggunakan model pembelajaran Think Pair Share (TPS) mengalami peningkatan. Hal ini dibuktikan dengan perolehan nilai pada Posttest dikatakan tuntas karena dari siswa yang telah mencapai SKM, dengan nilai ketuntasan $100 \%$. Kormiana (2017) menjelaskan pada siklus II rata-rata kelas yang diperoleh adalah 85.3 dengan kategori baik, ketuntasan klasikal 94.4\% dengan kategori tuntas karena telah mencapai $>85 \%$ siswa mencapai KKM. Seperti yang dijelaskan oleh Wulandari (2013) jika Sebelum dilakukannya penelitian siswa dikelas XI IPA 4 hanya sekitar 16 siswa yang tuntas mencapai nilai KKM yaitu 75. Setelah dilakukannya perubahan dalam proses mengajar yaitu menggunakan Mind Mapping disertai Think Pair Share ternyata terjadi peningkatan terhadap hasil belajar kognitif. 
Selain itu hasil posttest siswa dapat meningkat karena siswa merasa antusias dengan suasana yang baru mereka temui karena model pembelajaran Think pair share (TPS) merupakan model pembelajaran yang dapat diterapkan untuk membuat variasi suasana pola diskusi. Didukung oleh pendapat Trianto (2007) model pembelajaran Think pair share (TPS) merupakan model pembelajaran kooperatif yang efektif untuk membuat variasi suasana pola diskusi. Bakri, et al (2014) bahwa model pemblajaran TPS melibatkan aktivitas seluruh siswa, siswa bertanggung jawab dalam proses pembelajaran, dan juga mengandung unsure berfikir-berpasangan-berbagi sehingga siswa lebih aktif dan tidak bosan dalam kegiatan belajar. Puspitaningtyas (2016) menyatakan bahwa Model pembelajaran Think Pair Share merupakan jenis pembelajaran kooperatif yang dirancang untuk mempengaruhi pola interaksi siswa.

Aktivitas belajar siswa juga mempengaruhi hasil posttest yang diperoleh siswa, semakin baik aktivitas yang dilakukan siswa maka akan semakin tinggi pula pemahaman siswa tentang materi pembelajaran karena aktivitas mempengaruhi pola pikir. Sependapat dengan Wibowo (2016) menyatakan bahwa Partisipasi aktif siswa sangat berpengaruh pada proses perkembangan berpikir, emosi, dan sosial. Lebih lanjut Kasih, et al (2013) menjelaskan bahwa penerapan model pembelajaran TPS berpengaruh signifikan terhadap peningkatan hasil belajar siswa. Hal itu ditunjukkan oleh nilai pretest, posttes data $N$-gain siswa. Peningkatan hasil belajar tersebut dikarenakan adanya peningkatan aktivitas belajar yang dilakukan oleh siswa selama proses pembelajaran berlangsung.

Mind Mapping akan membantu mensinergikan kinerja otak bagian kanan dan kiri karena siswa tidak hanya menulis dan membaca melainkan siswa akan menggambar dan mewarnai. Sesuai dengan pendapat Nengsih (2016) penggunaan gambar dan warna dalam pembelajaran memberikan efek yang baik dalam belajar. Media Mind Mapping akan mensinergikan kerja otak bagian kanan dan otak bagian kiri dimana memori yang tersimpan dalam otak kanan akan lebih lama diingat dibandingkan dengan otak bagian kanan. Sejalan dengan pendapat Shalihah (2014) bahwa Mind Map mensinergikan antara penggunaan otak kiri dan otak kanan yang saling membantu, menggunakan imajinasi dan asosiasi yang menghubungkan anatara satu dengan lainnya.

Mind Mapping yang menyeimbangkan kinerja otak kanan dan kiri akan membantu siswa untuk mengingat materi yang telah dipahami lebih lama. Tenriawaru (2014) menyatakan jika bahwa mind mapping menyeimbangkan kedua belahan otak, yaitu logika dan imajinasi. Sebagaimana yang kita ketahui bersama bahwa otak kiri bertanggung jawab terhadap logika sedangkan otak kanan bertanggung jawab terhadap imajinasi dan seni sehingga melalui implementasi mind mapping, peserta didik dapat menghasilkan lebih banyak ide, pembelajaran menjadi menyenangkan, dan memudahkan dalam memahami materi pelajaran. Santi, et al 
(2017) menyatakan Belajar dengan menggunakan mind map, menjadikan belajar tidak cepat bosan, materi pelajaran akan mudah untuk diingat, dan meningkatkan hasil belajar.

\section{SIMPULAN}

Berdasarkan hasil penelitian tentang pengaruh model pembelajaran Think Pair Share menggunakan media Mind Mapping terhadap aktivitas dan hasil belajar kognitif siswa kelas X IPA dan menggunakan model pembelajaran konvensional di SMAN 06 Kota Bengkulu dapat disimpulkan bahwa terdapat pengaruh model pembelajaran Think Pair Share menggunakan media Mind Mapping terhadap aktivitas siswa kelas X IPA di SMAN 06 Kota Bengkulu karena hasil uji t diperoleh nilai $p$-value atau sebesar 0.000. Terdapat pengaruh model pembelajaran Think Pair Share menggunakan media Mind Mapping terhadap hasil belajar kognitif siswa karena hasil uji t diperoleh nilai $p$-value sebesar 0.000

\section{DAFTAR PUSTAKA}

Alfiyana, A.N. \& Cholik, M. (2016). Penerapan Model Pembelajaran Kooperatif Tipe Think Pair Share (Tps) Untuk Meningkatkan Aktivitas Belajar Siswa Pada Mata Pelajaran Alat Ukur Kelas X Teknik Permesinan SMK Negeri 3 Jombang. JPTM 4(2); 75-84.

Amalia, N, Riyadi \& Sajadi, I. (2014). Eksperimentasi Model Pembelajaran Kooperatif Tipe Think Pair Share, Tipe Make A Match Dan Tipe Guide Note Taking Ditinjau Dari Gaya Kognitif Siswa Sma Muhammadiyah Kota Surakarta. Jurnal Elektronik Pembelajaran Matematika 2(3); 327-336.

Bakri, M., Lestari, R. \& Ade, F.Y. (2014). Pengaruh Pembelajaran Kooperatif Tipe Think Pair Share Padamateri Sistem Pencernaan Manusia Terhadap Hasil Belajar Biologi Siswa Kelas VIII SMP Negeri 1 Kepenuhan Hulu Tahun Pembelajaran 2014/2015. Skripsi. FKIP Biologi UPP. Riau.

Burzan, T. 2010. Buku Pintar Mind Mind. PT Gramedia Pustaka Utama. Jakarta.

Dina, I.F. (2018). Pengaruh Model Pembelajaran Think Pair Share Terhadap Kemampuan Berpikir Kritis Dan Kemandirian Belajar Peserta Didik Pada Mata Pelajaran Biologi Kelas X Di SMAN 2 Bandar Lampung. Skripsi. Fakultas Tarbiyah Dan Keguruan Universitas Islam Negeri Raden Intan. Lampung

Elita, U. (2018). Peningkatan Hasil Belajar Menggunakan Metode Pembelajaran Mind Mapping. BIOEDUSAINS: Jurnal Pendidikan Biologi Dan Sains, 1(2), 177-182. https://doi.org/https://doi.org/10.31539/bioedusains.v1i2.372

Hastutin, S.Y., Hastuti,A. \& Lufri. (2012). Pengaruh Model Kooperatif Tipe Think Pair Share (TPS) Disertai LKS Bernuansa Mind Map Terhadap Kompetensi Belajar Biologi Siswa Di Kelas X MAN 3 Kerinci. Skripsi. FKIP PPS UNP. Padang. 
Heriadi. (2015). Penerapan Mind Mapping pada Pembelajaran Biologi Konsep Sistem Pernapasan Manusia terhadap Peningkatan Aktivitas dan Hasil Belajar Siswa. Seminar Nasional XII Pendidikan Biologi FKIP UNS. Banjarmasin.

Kasih, F.C., Jalmo, T., \& Bintoro, A. (2013). penggunaan model pembelajaran kooperatif tipe TPS terhadap aktivitas dan hasil beljar siswa. Skripsi. FKIP Biologi Unila. Lampung.

Khodijah, D.N., Hendri, \& M. Darmaji. (2016). upaya meningkatkan partisipasi dan hasil belajar dengan menggunakan model pembelajaran kooperatif tipe think pair share di kas XI MIA SMAN 1 Muaro Jambi. Jurnal Edufisika 1(2);24477935.

Kormiana M.S. (2017). Metode Think Pair Share (Tps) Untuk Meningkatkan Hasil Belajar Bahasa Inggris Siswa Sekolah Menengah Pertama. Jurnal Ilmu Pendidikan Sosial, sains, dan Humaniora 3(1);61-69.

Kurniawati, D., Al Habib, I., \& Sukamto, D. (2018). Pengaruh Science Comic terhadap Hasil Belajar Siswa. BIOEDUSAINS: Jurnal Pendidikan Biologi Dan Sains, 1(2), 106-114. https://doi.org/https://doi.org/10.31539/bioedusains.v1i2.455

Lestari, S.K. \& Ningrum. (2016). Pengaruh Penggunaan Cooperative Learning Tipe Thinkpair-Share (TPS) Terhadap Hasil Belajar Kewirausahaan Siswa Kelas X Semester Genap SMK Kartikatama 1 Metro Tahun Ajaran 2015/2016. Jurnal FKIP UM Metro 4(1);21-34.

Lie, A. (2008). Mempaktikan Cooperative Learning Diruang-Ruang Kelas. PT.Gresindo Jakarta.

Maesaroh, S. (2013). Peranan Metode Pembelajaran Terhadap Minat Dan Prestasi Belajar Pendidikan Agama Islam. Jurnal Kependidikan 1(1);150-168

Marlina, L., Habisukan, U.H., \& Arfika, D. (2017). Pengaruh Penerapan Model Tps (Think Pair Share) Terhadap Minat Belajar Siswa Kelas VII Pada Mata Pelajaran Biologi Di MTS Negeri 1 Palembang. Jurnal Bioilmi 3(1);25-37

Muslima, Sahputra, S., \& Melati, H.A. (2015). Pengaruh Model Pembelajaran Think Pair Share Terhadap Hasil Belajar Dan Aktivitas Siswa SMA. Skripsi. FKIP Untan. Pontianak.

Nengsih, W. (2016). Penerapan Metode Diskusi Dengan Media Mind Mapping Dalam Upaya Peningkatan Hasil Belajar. Jurnal Curricula 2(1); 23-32.

Nesi, M., \& Akobiarek, M. (2018). Pengaruh Minat dan Penggunaan Metode terhadap Hasil Belajar IPA Biologi Siswa Kelas VII SMP Negeri 2 Jayapura. BIOEDUSAINS: Jurnal Pendidikan Biologi Dan Sains, 1(1), 80-94. https://doi.org/https://doi.org/10.31539/bioedusains.v1i1.257

Nuyami, Suastra \& Sadia. (2014). Pengaruh Model Pembelajaran Kooperatif Tipe Thinkpair-Share Terhadap Self-Efficacy Siswa Smp Ditinjau Dari Gender. eJournal Program Pascasarjana Universitas Pendidikan Ganesha vol.4.

Pembelajaran terhadap Hasil Belajar Biologi. BIOEDUSAINS: Jurnal Pendidikan Biologi Dan Sains, 26-32. https://doi.org/https://doi.org/10.31539/bioedusains.v2i1.620 
Prasetyawati, P. (2016). Analisis Proses Pembelajaran Berbasis Student Centered Learning Dalam Pendekatan Saintifik Pada Mata Pelajaran Sejarah Di SMA Negeri Se Kota Palu. E-Jurnal Katalogis 4(10); 130-137.

Pusparini, S.A. (2015). Efektivitas Lesson Study Pada Mata Pelajaran Ekonomi Untuk Meningkatkan Motivasi Dan Prestasi Belajar Siswa Kelas X SMA Negeri 11 Yogyakarta. Skripsi. Fakultas Ekonomi UNY. Yogyakarta.

Rosba, E. (2015). Peningkatan Aktvitas Dan Hasil Belajar Siswa Menggunakan Model Pembelajaran Thi Pair Share Yang Disertai LKS Pada Mata Pelajaran IPA Biologi Kelas VII A SMPA Taman Siswa Padang. Jurnal BioConcetta 1(2); 2460-8556.

Rozi, Z., Harmoko, H., \& Teresa, F. (2018). Pengaruh Model Cooperative Script terhadap Aktivitas dan Hasil Belajar Biologi Siswa Kelas VIII SMP Negeri 7 Lubuklinggau. BIOEDUSAINS: Jurnal Pendidikan Biologi Dan Sains, 1(1), 23-33. https://doi.org/https://doi.org/10.31539/bioedusains.v1i1.256

Saenab, S. \& Puspita, I. (2012). Peningkatan aktivitas dan hasil belajar biologi melalui peneapan model pembelajarn kooperatif tipe think pair share (TPS) pada siswa kelas XI IPA 2 SMAN 1 Mangkutana. Jurnal Bionature 13(2); 127-135.

Samitra, D., Krisnawati, Y., \& Malasari, N. (2018). Pengaruh Model Guided Note Taking terhadap Hasil Belajar Biologi Siswa Kelas XI SMA Negeri 6 Kota Lubuklinggau. BIOEDUSAINS: Jurnal Pendidikan Biologi Dan Sains, 1(1), 1-10. https://doi.org/https://doi.org/10.31539/bioedusains.v1i1.237

Santi, V.P., Abdat, Chadidjah \& Makhmudah, U. (2017). Pengembangan Panduan Mind Mapping untuk Meningkatkan Keterampilan Belajar. Jurnal Program Studi Bimbingan dan Konseling 5(2); 96-100.

Saputra, N., Darmandi \& Linggasai, M.N. (2015). Penerapan Model Pembelajaran Cooperative Type TPS (Think Pair Share) Untuk Meningkatkanhasil Belajar IPA VII C MTS Hubbul Wathan Bagan Punak Tahun Pelajaran 2015/2016. Skripsi. FKIP Universitas Riau. Riau.

Silberman, M. (2007). Active Learning : 101 Strategi Pembelajaran Aktif. Pustaka Insane Madani. Yogyakarta.

Solikhin, M. (2015). Upaya Meningkatkan Keberanian Siswa Bertanya Dan Prestasi Belajar Dengan Pembelajaran Think Pair Share (TPS) Berbantuan Media. Jurnal Pendidikan 16(2); 74-99.

Sundari, S. (2018). Peningkatan Hasil Belajar Biologi dengan Model Discovery Learning. BIOEDUSAINS: Jurnal Pendidikan Biologi Dan Sains, 1(2), 143154. https://doi.org/https://doi.org/10.31539/bioedusains.v1i2.449

Surraya, L., Subagian, I.W \& Tika, I.N. (2014). Pengaruh Model Pembelajaran Think Pair Share Terhadap Hasil Belajar IPA Ditinjau Dari Keterampilan Berpikir Kritis Siswa. e-Journal Program Pascasarjana Universitas Pendidikan Ganesha vol.4.

Suryanto. (2009). Perilaku Kelompok Dan Individu. Jurnal Kependidikan 2(1); 1-9.

Tenriawaru, E.P. (2014). Implementasi Mind Mapping Dalam Kegiatan Pembelajaran Dan Pengaruhnya Terhadap Pendidika Karakter. Skripsi. Fakultas Sains Biologi Universitas Cokroaminoto Palopo. Makasar. 
Trianto. (2007). Model-Model Pembelajaran Inovatif Berorientasi Kontruktivistik. Prestasi Pustaka. Jakarta.

Undang-Undang No. 20 Tahun 2003 Tentang Sistem Pendidikan Nasional. Media Wacana Press. Yogyakata.

Wardhani, A.I., Masykuri, M. \& Utami, B. (2014). Pengaruh Model Pembelajarab Kooperatif Model Think Pair Share (TPS) Menggunakan Strategi Peta Konsep Dan Peta Pikiran Terhadap Prestasi Belajar Siswa Materi Ikatan Kimia Kelas XI SMAN 1 Karanganyar Tahun Ajaran 2013/2014. Jurnal Pendidikan Kimia $3(2) ; 36-44$.

Wibowo, N. (2016). Upaya Peningkatan Keaktifan Siswa Melalui Pembelajaran Berdasarkan Gaya Belajar Di Smk Negeri 1 Saptosari. Jurnal Electronics, Informatics, and Vocational Education (ELINVO) 1(2).

Wulandari, S. (2013). Penerapan Strategi Mind Map Disertai Thinkpair Share (TPS) Untuk Meningkatkan Hasil Belajar Biologi Pada Kelas XI IPA 4 SMAN Kebakkramat Karangnayar Tahun Ajaran 2012/2013. Skripsi. FKIP Biologi UMS. Surakarta. 